\section{Dennis Healy Neville}

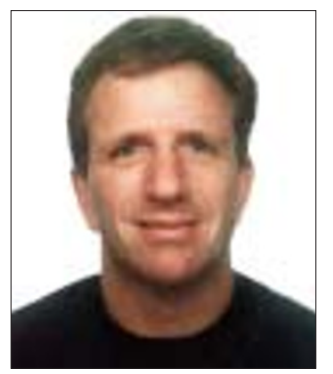

Dennis died tragically on 27 February 2003, aged 43 years. Dennis was born in Bishop Auckland on 27 October 1959, the third child to Mrs Toni Neville of Gainford, County Durham and the late Dr Bill Neville.

He was educated at St Mary's Primary School, Barnard Castle and Mount St Mary's College, Sheffield from 1971 to 1978 where his lifelong trait of enthusiasm mated with a slight-

ly reckless streak resulted in him nearly burning the school down with an unauthorised out of hours chemistry experiment.

Having survived school, Dennis then came to King's College Hospital, London where he embarked on an undergraduate career which can only be described as legendary, as all who were at Kings from 1978 to 1982 will know exactly what I mean. Although the staff at the time may have been more exasperated than amused.

Dennis was a stalwart of the rugby club, and was especially proud of being the third team captain, but he made the mistake of thinking the team subscriptions were his to spend on team beers, which resulted in a rather large bill at the end of the season. It was during this time at a rugby club disco at 'Doggers' that he met his future wife Alison.

Having qualified in 1982, Dennis carried on his life in very much the same vein though worryingly with more money and faster cars. After different associate positions in South London, Dennis and Alison moved back to his home ground of Darlington, where his two adored children, Jessica and Jack, were born.

Dennis bought his practice in Darlington and, probably to the surprise and delight of many, built up a thriving modern practice, eventually moving into the field of implants and major restorative work. He was also a VT trainer for many years.

\section{Erica Weindling}

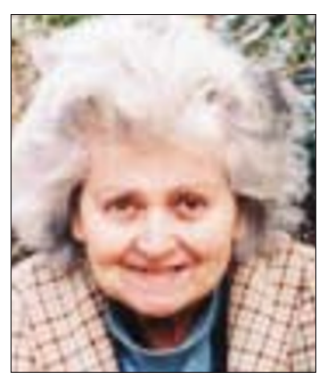

Erica Weindling died on 7 November 2002. She studied dentistry at University College Hospital Dental School, and qualified LDS RCS in 1952. In 1975 she took over her husband's surgery at 29a Connaught Street, London W2, which she ran for over twenty years. She was also dental officer at Friern Hospital until its closure, greatly enjoying the interest of her patients.

She was forced to leave her school after the Nazi takeover of Austria. She came to Britain on a Kindertransport, arriving on 13 January 1939 and stayed in Highgate with the family of Professor A.V. Hill, the Secretary of the Royal Society and Nobel laureate in physiology.
He was educated at Mount St Mary's College, Sheffield from 1971 to 1978 where his lifelong trait of enthusiasm mated with a slightly reckless streak resulted in him nearly burning the school down with an unauthorised out-of-hours chemistry experiment.

Dennis spent a lot of time playing sports. He was a gifted golfer and even ran the London Marathon. His theory for running, squash and general fitness training was that it allowed him to eat, drink and smoke all he wanted.

Dennis had many fine qualities, probably too many to mention. He had a generosity of spirit which made any time spent with him a joy. He was a wonderful man who no one had a bad thing to say about. To know him was to love him and like most truly attractive people he had no idea how much we all loved him, and he would be squirming with embarrassment if he could read this now.

Our love and thoughts must now be with Alison, Jessica, Jack and all who have been left behind.

It breaks my heart to know we will never see those vivid blue eyes atop that slightly-too-big a nose ever again. The world has lost a truly wonderful man.

Jonathan Yates

Born Erika Gutmann in Vienna on 29 July 1921, she was forced to leave her school after the Nazi takeover of Austria. She came to Britain on a Kindertransport, arriving on 13 January 1939 and stayed in Highgate with the family of Professor A.V. Hill, the Secretary of the Royal Society and Nobel laureate in physiology. She enrolled at the Regent Street Polytechnic, which was evacuated to Lancaster and in 1941 she passed her Matriculation examination. She then studied for pre-medical qualifications at Chelsea College from 1942-1944.

She supported the busy wartime dental practice of Emmerich Weindling MD, LDS RCS Eng. (1906 - 1975), when much dental work was done for the Dutch merchant navy. He was one of the forty Austrians allowed to study dental surgery in 1939, and requalified at Guy's Hospital.

Erica was overjoyed to hear that her parents and sisters survived the Holocaust, and Erica and Emmerich married in 1946. They became British citizens in 1949, when Michael was born. A second child was stillborn, Paul happily followed in 1953 and Oliver in 1955.

Erica took much pleasure in her house and garden in Highgate, and had a lively interest in the arts and history. A high point of her later years was to fulfil a life long ambition to visit Tibet. She was vivacious, liberal and tolerant in outlook, and immensely warmhearted. Her decline due to Alzheimer's was mercifully gentle.

Paul Weindling 